\title{
Carnets
}

Revue électronique d'études françaises de l'APEF

Première Série - 1 Numéro Spécial | 2009

Cultures littéraires : nouvelles performances \& développement

\section{Da poética inter-artes ao zapping cultural...}

Maria Rosário Girão Ribeiro dos Santos et Manuel José Silva

\section{OpenEdition}

Journals

Édition électronique

URL : http://journals.openedition.org/carnets/4093

DOI : $10.4000 /$ carnets.4093

ISSN : 1646-7698

Éditeur

APEF

Édition imprimée

Date de publication : 1 juin 2009

Pagination : pt

Référence électronique

Maria Rosário Girão Ribeiro dos Santos et Manuel José Silva, « Da poética inter-artes ao zapping cultural... ", Carnets [En ligne], Première Série - 1 Numéro Spécial | 2009, mis en ligne le 16 juin 2018, consulté le 01 mai 2019. URL : http://journals.openedition.org/carnets/4093 ; DOI : 10.4000/ carnets.4093

\section{(2) $(1) \Theta$}

Carnets est mis à disposition selon les termes de la licence Creative Commons - Atribution - Pas d'utilisation commerciale 4.0 International. 


\title{
DA POÉTICA INTER-ARTES AO ZAPPING CULTURAL...
}

\author{
MARIA do ROSÁRIO GIRÃo RIBEIRO dOS SANTOS \\ MANUEL JOSÉ SILVA \\ Universidade do Minho \\ rosario@ilch.uminho.pt
}

\section{Resumo}

Haverá, porventura, suporte mais relevante para o mito literário do que as artes figurativas? Longe de se reduzirem a meras ilustrações, elas conferem-Ihe, como texto "outro", uma expressão inédita, passível de esclarecimento de um qualquer detalhe que a 'versão' literária negligenciou. Assim é que a iconografia esteve, desde os tempos primordiais eliadianos, ao serviço da mitologia... Suportes não literários, as inter-artes, que não deixam de se assumir, no âmbito dos estudos comparatistas, como um veículo essencial de expansão e de 'modernização' incessantes do mito, tendem para os jogos interactivos, praticando um sincretismo por vezes brutal e amalgamando substratos míticos heterogéneos. Não tenderia a especificidade da literatura "tout court" a delir-se paulatinamente se não fosse esta globalização da cultura e esta universalização de uma linguagem plural?

\section{Abstract}

Will there be a more relevant basis for the literary myth than figurative arts? Far from being no more than mere illustrations, they endow this "other" text with a novel expression, one that invites clarification of any minor details overlooked in the literary 'version'. Such has been the role of iconography at the service of mythology... The inter-arts, which assert themselves in the field of comparative studies as an essential vehicle for a permanent expansion and 'modernisation' of myth, tend to favour, as non-literary means of expression, the interactive games, practising a, sometimes, brutal syncretism, and amalgamating myhthical heterogeneous substrata. One wonders whether the specificity of literature, "tout court", would not tend to slowly vanish, were it not for this globalisation of culture and this universalisation of a plural language?

Palavras-chave: Mitologia, Poética inter-artes, Zapping cultural, Linguagem plural Keywords: Mythology, Inter-arts poetics, Cultural zapping, Plural language 
Não se aparentará geneticamente a arte ao mito, susceptível de ser definido como uma estrutura simbólica de imagens espoletadora da criação artística? Do mesmo modo, não necessitará esta última de se apoiar na narrativa do primeiro acto criador, remontando aos tempos primordiais eliadianos? Por seu turno, tal recriação literária (e também plástica...) não poderá ser encarada como um modo de perpetuação da matriz semântica do mito? Finalmente, não passará a dialéctica a nível da criação por um duplo processo de desmitificação e de remitificação ${ }^{1}$

Nesta linha de pensamento parece situar-se, conquanto de modo não explícito, Étienne Souriau, ao considerar a arte tanto em termos de "dialectique de la promotion anaphorique" ou de "sagesse instaurative" como numa perspectiva de "activité instauratrice", ou seja, um "ensemble des démarches, orientées et motivées, qui tendent expressément à conduire un être [...] du néant ou d'un chaos initial jusqu'à l'existence complète, [...]" (Souriau, 1969: 45). A interacção arte-mito é, igualmente, aflorada por Hans-Georg Gadamer, quando advoga a sua concepção de arte não só como um desvendamento do oculto, mas também como uma experiência do arcano.

La obra de arte es una declaración que no constituye ninguna frase enunciativa, pero que es lo que más dice. Es como un mito, como una leyenda, precisamente porque tanto retiene lo que dice como, a la vez, lo brinda. La declaración hablará siempre, una y otra vez. (Gadamer, 2006: 295).

Afigura-se inquestionável, nesta sequência, a assunção do mito literário ${ }^{2}$ como 'terreno' fertilmente propício aos Estudos Interartes, a essa visão contrastiva e integrante que subjaz à "iluminação mútua das artes", mediante a transposição aplicada dos conceitos e dos métodos de uma dada arte numa arte outra. Com efeito, e na óptica de Claus Clüver (Clüver, 2002:333-359), foram os "Cultural Studies", a instituição dos novos discursos transdisciplinares (entre os quais a antropologia, a linguística e a informática) e a

\footnotetext{
${ }^{1}$ Ver, a este respeito, Wunenburger, Jean-Jacques (2005: 69-84), "Création artistique et mythique".

${ }^{2}$ Por razões de clareza, quedemo-nos nas definições de Pierre Brunel et de Philippe Sellier. Para este último, "Le mythe littéraire - si nous acceptons provisoirement de supposer tels quelques récits auxquels cette dénomination n'est pas discutée (Antigone, Tristan, Don Juan, Faust) - ne fonde ni n'instaure plus rien. Les œuvres qui l'illustrent sont d'abord écrites, signées par une (ou quelques) personnalité singulière. Évidemment, le mythe littéraire n'est pas tenu pour vrai. Si donc il existe une sagesse de langage, c'est du côté des trois derniers critères qu'une parenté pourrait se révéler entre mythe et mythe littéraire. Et de fait - indice encourageant - on ne peut à leur propos répondre aisément par la négative. Logique de l'imaginaire, fermeté de l'organisation structurale, impact social et horizon métaphysique ou religieux de l'existence, voilà quelles questions l'étude du mythe invite à poser au mythe littéraire." [Qu'est-ce qu'un mythe littéraire ?" in Littérature no 55 (octobre 1984: $113,115)]$. Na perspectiva de Pierre Brunel, "[...] je réserverai le terme de 'thème' pour un concept. [...] un mythe littéraire peut illustrer un thème : la figure mythique d'Antigone, par exemple, représente la révolte contre la loi [...] c'est parfois aussi la littérature qui en a l'initiative : tout ce que la littérature a transformé en mythes." (1988: 7,15).
} 
canalização do discurso interartístico para o sistema universitário ${ }^{3}$ que transmutaram 0 estudo comparatista das artes em Estudos Interartes. Assim sendo, as artes são, actualmente, encaradas como construtos culturais sujeitos a alterações, identificando-se a obra de arte com um texto elaborado segundo um determinado sistema sígnico e suspendendo-se a categorização estética, primacialmente caracterizada pelo Belo, lugar inclassificável que, segundo Remo Bodei (1997), não pertence ao domínio da realidade absoluta nem ao campo do mero inexistente, e que, na opinião de Elio Franzini e de Maddalena Mazzocut-Mis, "realizza, [...] a partire dall'Ottocento, l'ambiguità che già era nelle sue origini, manifestandosi ormai soltanto, secondo la definizione di Baudelaire, in quanto elemento duplice" (1996: 156). Cumpre explicitar, igualmente, que a arte não é nem filosofia, "perché [...] è intuizione irriflessa dell'essere", nem História, "perché la storia importa critica distinzione tra realtà e irrealtà" (Croce, 2001: 197), à imagem e semelhança do mito, detentor, a nível epistemológico, de uma lógica do ambíguo e do equívoco.

Paralelamente à supracitada evolução da poética inter-artes, e graças à abordagem semiótica que concebe os produtos de todas as manifestações artísticas como textos passíveis de leitura, também o mito literário foi sendo gradualmente revitalizado por modos de expressão particular (mito teatralizado e mito coreografado), bem como pela abordagem trans-histórica e interdisciplinar de Gilbert Durand (mediante o recurso à análise literária, à história da arte, à etnologia, à filosofia, à psicanálise e, até, às ciências exactas), cristalizada nos conceitos de mitocrítica e de mitanálise.

Urge, porém, neste contexto teórico preambular, estabelecer a distinção entre os estudos tradicionais inter-artes (na esteira das correspondências ${ }^{4}$ oitocentistas preconizadas por Charles Baudelaire, pelas "Voyelles" de Arthur Rimbaud e pelo órgão dos licores de Des Esseintes) e os hodiernos Estudos Interartes: se, ab initio, se privilegiava a análise das relações entre dois sistemas sígnicos distintos (literatura e artes plásticas, literatura e música, literatura e dança), insistindo na dicotomia imagem/palavra ${ }^{5} \mathrm{com}$ incidência no vínculo comum entre as diversas artes ${ }^{6}$, hoje em dia forçoso se torna estabelecer as fronteiras entre textos multimédia, textos "mixed-media" e textos intermédia (também designados por textos intersemióticos ou híbridos). Enquanto os primeiros combinam textos

\footnotetext{
3 De assinalar o Ramo/Especialização em "Poéticas Interartes" do Mestrado em Teoria da Literatura (Departamento de Estudos Portugueses do Instituto de Letras e Ciências Humanas da Universidade do Minho), bem como a leccionação da unidade curricular "Mito e Literatura" nas últimas edições do Mestrado em Estudos Franceses.

${ }^{4}$ Segundo Mario Praz (1982: 19), "só temos o direito de falar de correspondências [...] nos casos onde haja intenções expressivas comparáveis e poéticas comparáveis, de par com meios técnicos correlatos."

${ }^{5}$ Tão importante se revela esta dicotomia que a revista Word/Image - A Journal of verbal/visual enquiry, editada pela "University of Pennsylvania", Ihe foi consagrada (Number I, Volume 24, January-March 2008).

"É de assinalar a existência quer de um "air de famille" entre as obras de arte de uma determinada época, subordinadas ao zeitgeist [espírito da época] e advindas do ductus ['mão' de cada época] - cujos elementos heterogéneos são denunciados por imitações posteriores -, quer de uma unidade latente ou manifesta nas produções variegadas do mesmo artista.
} 
separadamente coerentes e compostos em média diferentes (música com letra) e os segundos conciliam signos complexos insusceptíveis de se tornarem auto-suficientes fora do contexto inicial, os terceiros recorrem a dois ou a mais sistemas de média, surgindo inseparáveis os aspectos visuais, verbais, cinéticos e performativos dos seus signos (os quadros produzidos a partir de palavras pintadas e os desenhos gráficos derivados de letras exemplificam sobejamente esta terceira categoria taxinómica) (Clüver, 2001: 333-359). Não parece despiciendo, neste contexto, a intrusão de um breve excurso a respeito quer do esforço de superação, por parte de cada arte, das limitações impostas pelos respectivos materiais, mais ou menos dúcteis, quer da vacilação entre a função estética e a função comunicativa inerentes, em maior ou menor grau, às várias expressões artísticas. É dado sobejamente adquirido que as artes plásticas são, do ponto de vista de Jan Mukarovsky, aquelas "cujo material é constituído por corpos inanimados que actuam no espaço sem que se tenha de se levar em conta o tempo" (1990: 251), ressaltando a sua corporalidade no confronto com a música inefável, obviando-se o seu carácter inânime no paralelo com o movimento da dança e transparecendo a sua invariabilidade no cotejo com as variações da poesia. A intermedialidade, contudo, não deixa de afirmar a sua supremacia, apesar de cada arte reclamar e preservar os legítimos direitos da sua especificidade: por um lado, a poesia, maleável, opera descrições plasticamente coloridas, competindo a pintura ${ }^{7}$ com a poesia ${ }^{8}$ na abordagem de temas episódicos e retomando o cinema o ilusório espaço pictórico; por outro lado, a poesia prescinde do espaço que se torna crucial para o cinema, onde passa a englobar mudanças de plano (que interrompem a continuidade) e mudanças de cenário (que não suspendem a duração contínua). Interessante se torna referir, ainda no tocante à diferenciação entre as artes $^{9}$, o grau variável de oscilação entre a esfera artística e a esfera extra-artística: enquanto o artesanato moderno tende, de um modo cada vez mais acutilante, para a arte, ao invés da fotografia que, vulgarizada pelo pragmático retrato instantâneo, se demarca paulatinamente do campo artístico, a literatura assiste à emulação entre a função estética e a função comunicativa, assemelhando-se a obra de arte à palavra em situação de transmissão e de recepção: "[...] do mesmo modo que a manifestação

\footnotetext{
${ }^{7}$ Para Fernando Guimarães, a pintura "representa um modo de ver. Isto quer dizer que há uma íntima relação entre o espaço de representação e o lugar do espectador. [...] O quadro [...] deixa de ser uma janela e transforma-se num espaço que acaba por pôr em questão a verdade da representação. Poderíamos, talvez, dizer que a representação se transforma em apresentação [...]" (2003: 11-12). Partindo das "grandes narrativas" (terminologia tomada de empréstimo a Jean-François Lyotard), Fernando Guimarães debruça-se sobre quatro narrativas: "Primeira narrativa - a percepção", "Segunda narrativa: o espaço, o tempo e a gestualidade", "Terceira narrativa - a conceptualização" e "Quarta narrativa: a imitação e a imaginação".

${ }^{8}$ Ver, a este respeito, Les souffrances du jeune Werther (1973: 45): "Ce que je te disais dernièrement de la peinture peut certainement s'appliquer aussi à la poésie. II ne s'agit que de reconnaître le beau, et d'oser l'exprimer: c'est, à la vérité, demander beaucoup en peu de mots." (Carta de Werther datada de 30 de Maio e endereçada a Wilhelm).

9 É curiosa a distinção que Fernando Pessoa estabelece, na sua "Teoria da Literatura", entre a poesia e a música: "A poesia é a emoção expressa em ritmo através do pensamento, como a música é essa mesma expressão, mas directa, sem o intermédio da ideia. Musicar um poema é acentuar-lhe a emoção, reforçando-Ihe o ritmo." (1986: 89).
} 
linguística serve de intermediário entre dois indivíduos, [...] a obra de arte é destinada pelo seu autor a servir de meio de comunicação com os indivíduos receptores." (1990: 267).

Transitando para o mito, fácil se torna constatar que uma imagem se assume como um suporte tão válido quanto uma obra escrita ou uma narrativa oral, não se resumindo, por conseguinte, as artes figurativas a meras ilustrações: com efeito, se a escultura não se revelou a mais rica via de acesso ao conhecimento do mito, já a cerâmica não deixou de oferecer uma gama variada de representações míticas, datando do século VIII A.C. e privilegiando ora a figura negra a destacar-se num fundo vermelho de argila, ora a figura vermelha executada por contraste numa superfície negra.

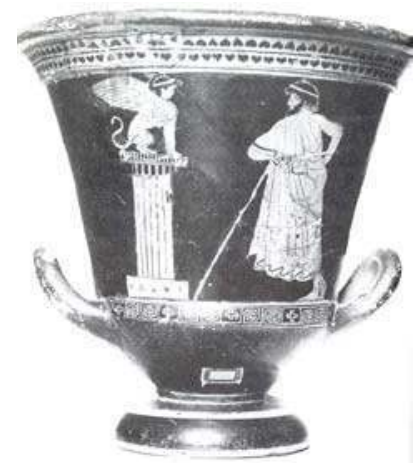

Figura 1 - Cratera de figuras vermelhas com Édipo e a Esfinge (470 a.C.) (Ruipérez, 2006: s/p).

Nesta sequência, o estabelecimento de um dossier iconográfico revela-se imprescindível à expansão do mito, como atestam sobremaneira as figuras de Édipo e da Esfinge, de Teseu e do Minotauro e, para mais não citar, desse Hércules dos doze trabalhos (Monneyron e Thomas, 2002: 82).

Uma das questões que tem atraído os Estudos Interartes centra-se, inequivocamente, na análise de relações entre séries de textos, representativos de um dado género ou de um determinado movimento e integrando duas ou mais artes, bem como nas conexões temáticas (afinidades e divergências) que eles nos autorizam a estabelecer numa dupla perspectiva sincrónica e diacrónica. Tomemos, como primeiro exemplo, o impressionismo, primacialmente caracterizado por três técnicas modernas: a relação entre a forma e a luz (efeito de diluição da forma-contorno na forma-mancha, constituindo a última não a descrição, mas antes a evocação da primeira), a triangulação do espaço e a sua "representação polisensorial" (Francastel, Pierre apud Vouilloux, 2007: 339-379). Se o impressionismo dá a sensação, pela sua estrutura fotoscópica e não microscópica - atentese na série de instantâneos 'tirados' por Claude Monet à Catedral de Rouen -, de escolher como musa inspiradora a fotografia e não a pintura, a literatura cedo se apresta a enveredar pela expressão verbal da mistura óptica de pinceladas, exaltando a luz e a cor, bem como 
pelo culto do esquisso e da evanescência dos contornos. É nesta perspectiva pictórica que Proust descreve os nenúfares 'da' Vivonne, reenviando intertextualmente este fragmento descritivo para o célebre quadro Bassin aux Nymphéas, recriado, por seu turno, nas ilustrações de Stéphane Heuet e na coloração de Véronique Doray, bastante fiéis, no nosso modesto entender, quer à pena em fuga de Proust quer ao fugidio pincel de Monet.

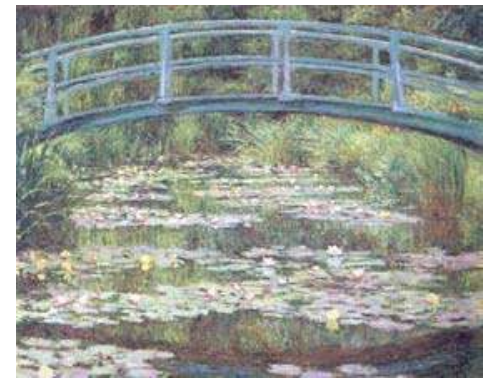

Figura 2 - Bassin aux nymphéas de Claude Monet (1996: 162).

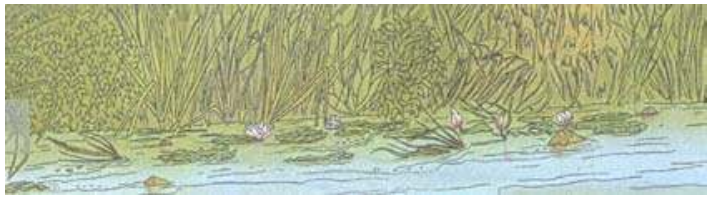

Figura 3 - Ilustração de Stéphane Heuet (1999: 64).

Comme les rives [Vivonne] étaient à cet endroit très boisées, les grandes ombres des arbres donnaient à l'eau un fond qui était habituellement d'un vert sombre mais que parfois, [...] j'ai vu d'un bleu clair et cru, tirant sur le violet, [...] Ça et là, à la surface, rougissait comme une fraise une fleur de nymphéa au coeur écarlate, blanc sur les bords. Plus loin, les fleurs plus nombreuses étaient plus pâles, moins lisses, plus grenues, plus plissées, et disposées par le hasard en enroulements si gracieux qu'on croyait voir flotter à la dérive, comme après l'effeuillement mélancolique d'une fête galante, des roses mousseuses en guirlandes dénouées. Ailleurs, un coin semblait réservé aux espèces communes qui montraient le blanc et le rose proprets de la julienne, [...] tandis qu'un peu plus loin, pressées les unes contre les autres en une véritable plate-bande flottante, on eût dit des pensées des jardins qui étaient venues poser comme des papillons leurs ailes bleuâtres et glacées sur l'obliquité transparente de ce parterre d'eau; [...] (Proust, 1984: 169-170).

$\mathrm{Na}$ senda de Proust $^{10}$, "o psicólogo"11, também Virginia Woolf, arauta de uma viragem na narrativa graças ao "fluxo da consciência", não raro se deleita em pintar com

\footnotetext{
${ }^{10}$ Virginia Woolf foi uma leitora atenta de Proust, como atesta o seguinte fragmento de uma epístola endereçada a Vita Sackeville-West e datada de [Monk's House (Rodmell, Sussex)] 30 de Agosto de 1928: "Por outro lado, devo trabalhar todo o dia num montão de romances, mas não consigo, ao que parece, mais do que produzir o ranger de uma faca embotada no contacto com uma mó. Leio Proust, Henry James, Dostoiewski; [...]" (1994: 49). ${ }_{11}$ Ver, a este respeito, carta de Virginia Woolf a Vita Sackeville-West, datada de [Monk's House (Rodmell, Sussex)] 29 de Junho de 1936, segunda-feira: "Proust, o psicólogo, tem um avanço imenso sobre Ronsard." (1994: 76).
} 
palavras quadros impressionistas ${ }^{12}$, praticando mesmo o pontilhismo - quando o Sol começa a sua ascensão, o orvalho, ao dançar na ponta das flores e das árvores, transforma o jardim num mosaico de brilhos que, isolados, ainda não se configuram num todo -, e em aplicar a técnica musical à estrutura do romance. Com efeito, algumas descrições de The Waves narrativa das vivências interiores (interiormente perspectivadas, após a sua detecção nos arcanos do espírito), da infância à velhice, de Neville (definido em termos de ordem e rigor), de Bernard (exímio na selecção de palavras e na construção de frases), de Louis (determinado, embora detentor de um complexo de inferioridade), de Susan (aliciada pela unidade da vida familiar), de Jinny (obcecada pela sua imagem sensual ao espelho) e de Rhoda (caracterizada pela sua eterna insegurança) - 'prolongam' a descrição proustiana, mormente no tocante aos diversos ângulos de incidência do sol, às projecções de estrias de sombras e ao trémito do orvalho nas flores e nas folhas. Grafadas em itálico, as referências ao Sol que ainda não rompeu, ao Sol que se eleva um pouco mais, ao Sol que acaba por nascer, ao Sol que olha de frente para as ondas, ao Sol que atinge o seu ponto mais alto, ao Sol que inicia o seu declínio, ao Sol que começa a decair e ao Sol que definitivamente se põe vão ritmando a trajectória, resumida no monólogo final do envelhecido Bernard ${ }^{13}$, dos seis amigos, para os quais a morte de Percival - que eles adoravam - constitui um marco de relevo. Por seu turno, as três divisões de To the Lighthouse correspondem a três andamentos musicais, remetendo o primeiro e o terceiro para uma viagem da família Ramsey ao farol, gorada na primeira parte e concretizada na parte terceira. Aliás, a busca de uma "little language" não deixou de constituir uma das preocupações fulcrais da escritora londrina: "What is the phrase for the moon? And the phrase for love? By what name are we to call death? I do not know. I need a little language such as lovers use, words of one syllable such as children speak when they come into the room, [...]" (Woolf, 1992: 183). Também A Arte da Fuga, de Álvaro Manuel Machado, é estruturada pela música de Bach, que, em seis movimentos, desencadeia uma verdadeira poética da memória e da escrita: "I. Fugas simples. II. Fugas strette. III. Fugas a duas vozes. IV. Fugas em espelho. V. Cânones. VI. Fuga final a quatro vozes." (1983).

Nesta livre transição que as artes autorizam, ao facultarem contactos frutíferos entre textos verbais e não verbais, o princípio ecfrástico, "caso mais extremo e revelador do potencial visual e espacial do medium literário" (Krieger, 2007: 138), desempenha um papel

\footnotetext{
12 Ver, sobre o assunto, a "Introduction" de Sandra Kemp às Selected Short Stories de Virginia Woolf: "Yet despite its difficulties, she could not resist 'the flying phrase', and she urged her sister Vanessa to follow her example: 'I should like to paint a large, large, picture; where everything would be brought perfectly firmly together, yet all half flying off the canvas in rapture.' [...]" (1993: ix-x).

${ }_{13}$ Assinalamos, de passagem, a reflexão metalinguística que perpassa em The Waves, sobretudo através de Bernard: "falsário de palavras", esta personagem, de um verbalismo altamente criador, advoga que uma boa frase tem existência própria e que as palavras, facilmente adaptáveis, não param de surgir. Chega, aliás, a pendurar as frases como se estivessem num roupeiro à espera de serem usadas...
} 
crucial: ao pressupor a dependência de uma arte em relação a outra, a écfrase questiona os limites pictóricos das palavras, como que as forçando não tanto a representar o visual, mas a rivalizar com o carácter espacial da pintura. Atentemos, doravante, no mito de Salomé, mais concretamente nas Salomés verbalmente 'parafraseadas' por Des Esseintes (herói kierkegaardiano) e por Huysmans nessa "Bíblia' da decadência que é À Rebours.

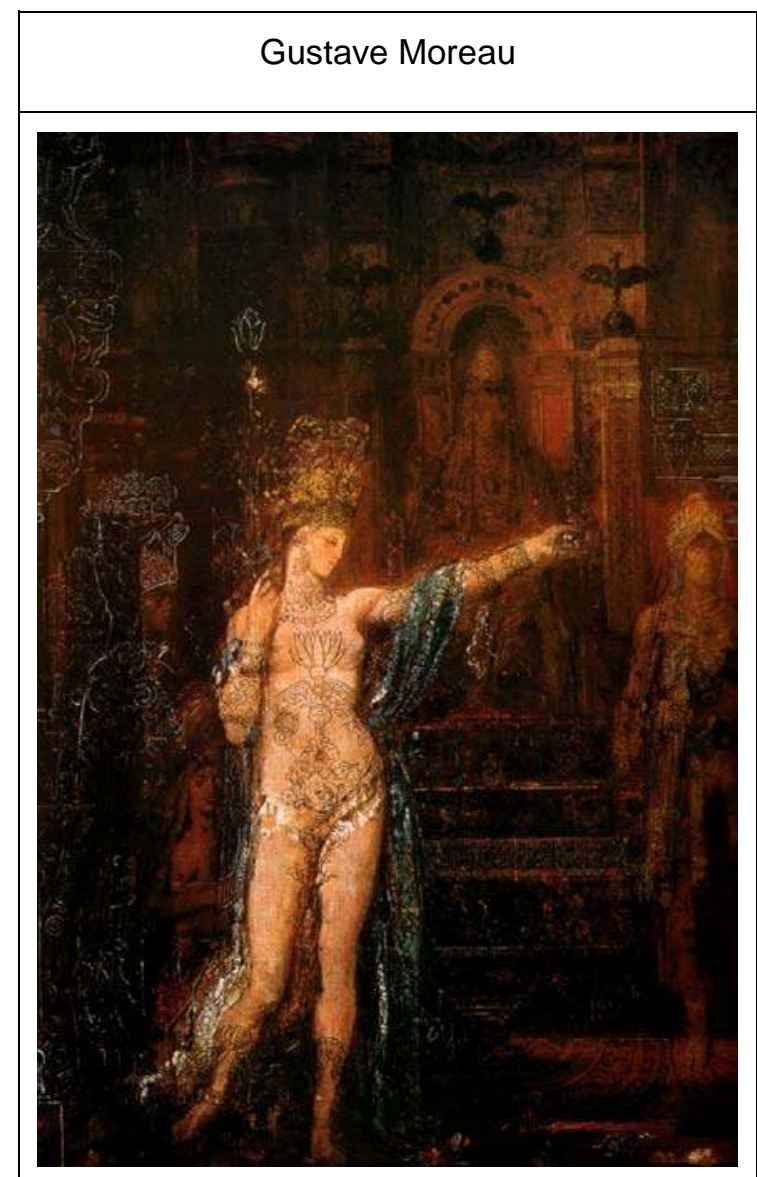

Figura 4 - "Salomé dansant devant Hérode" (Gustave Moreau/Amherst College).
Huysmans

"II [Des Esseintes] avait acquis ses deux chefsd'oeuvre [de Gustave Moreau] et, pendant des nuits, il rêvait devant l'un d'eux, le tableau de la Salomé, ainsi conçu: Un trône se dressait, pareil au maître-autel d'une cathédrale, sous d'innombrables voûtes jaillissant de colonnes trapues ainsi que des piliers romans, émaillées de briques polychromes, [...] Au centre du tabernacle surmontant l'autel précédé de marches en forme de demi-vasques, le Tétrarque Hérode était assis, coiffé d'une tiare, [...] La figure était jaune, parcheminée, cannelée de rides, décimée par l'âge; [...] Dans l'odeur perverse des parfums, dans l'atmosphère surchauffée de cette église, Salomé, le bras gauche étendu, en un geste de commandement, le bras droit replié, tenant à la hauteur du visage, un grand lotus, s'avance lentement sur les pointes, [...] La face recueillie, solennelle, presque auguste, elle commence la lubrique danse qui doit réveiller les sens assoupis du vieil Hérode; ses seins ondulent et, au frottement de ses colliers qui tourbillonnent, leurs bouts se dressent; [...] sur sa robe triomphale, couturée de perles, ramagée d'argent, lamée d'or, la cuirasse des orfèvreries dont chaque maille est une pierre, entre en combustion, croise des serpenteaux de feu, grouille sur la chair mate, [...] Quoi qu'il en fût, une irrésistible fascination se dégageait de cette toile, mais l'aquarelle intitulée L'Apparition était peut-être plus inquiétante encore. Là, le palais d'Hérode s'élançait, ainsi qu'un Alhambra, sur de légères colonnes [...] Le meurtre 


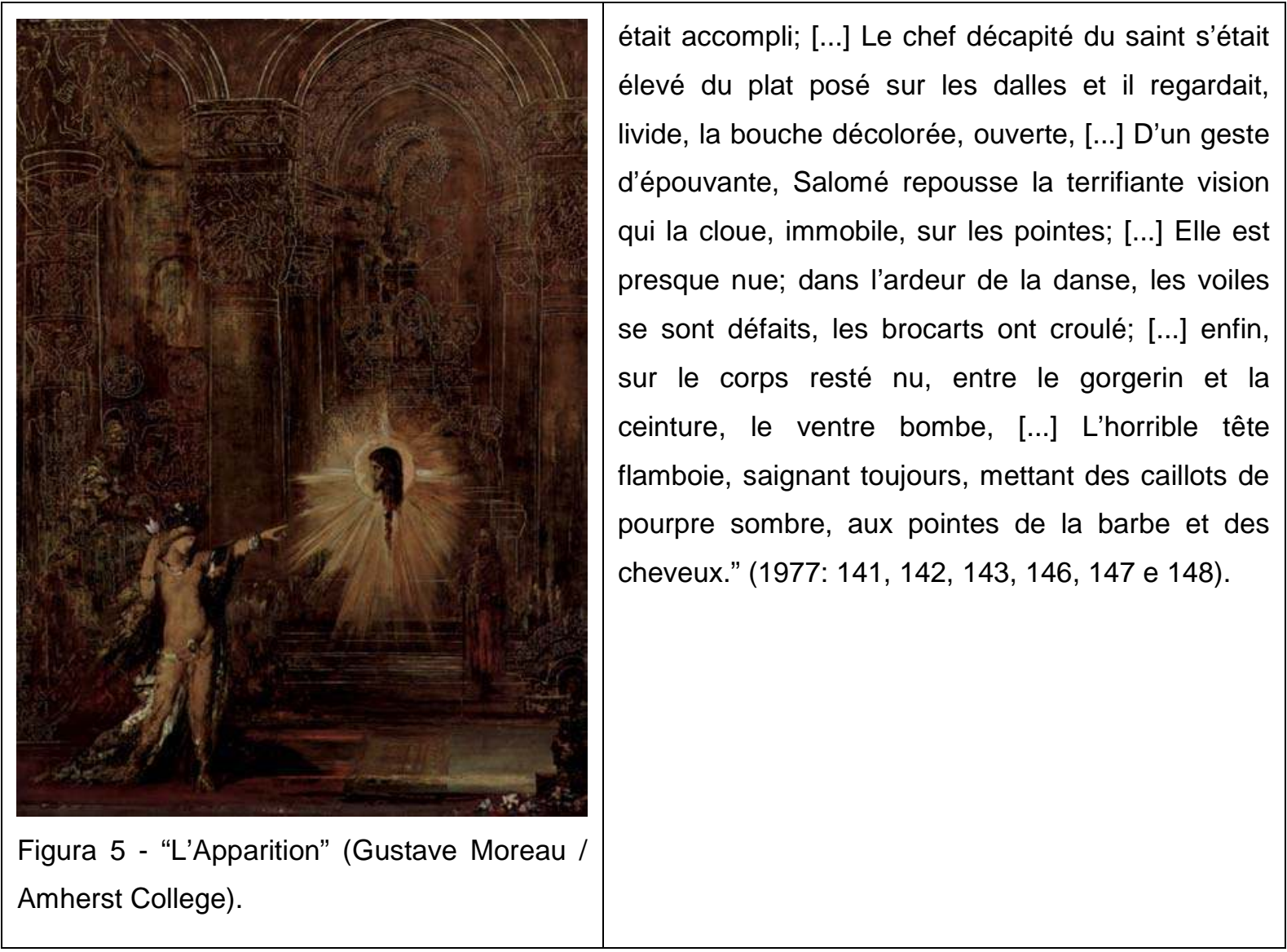

O enciclopedismo e o sincretismo, remetendo para a erudição do pintor, tornam-se cristalinos: se, na primeira tela, se sobrepõem a Idade Média ("maître-autel d'une cathédrale"), o Médio Oriente medieval (arquitectura "musulmane et byzantine") e o Oriente ("dieu Hindou"), coexistem, na segunda, as artes decorativas moçárabes e a faustosa joalharia que exacerba a sensualidade da mulher fatal ${ }^{14}$. Estamos, verdade seja dita, perante uma abordagem sincrónica do mito (os quadros em apreço de Gustave Moreau, contemporâneo de Huysmans, foram expostos no Salon de 1876 e, posteriormente, na Exposition Universelle de 1878) - contemplada pelos Estudos Interartes -, que suscita, como perspicazmente alertou Yves Chevrel (2006: 80-81), o levantamento de algumas questões capitais: haverá, em dados momentos da História, figuras míticas privilegiadas? Poderá um certo mito literário resumir uma época determinada? Será legítimo falar de uma sociologia do mito e de uma sociologia do estético? Aventuremo-nos brevemente nesta via mediante dois exemplos que reputamos dilucidativos: 1787 é, em simultâneo, a estreia de Don

\footnotetext{
${ }^{14}$ Numa perspectiva diacrónica, seria de todo o interesse incluir na 'galeria' das Salomés quer alguns fragmentos da Salomé legada por Fernando Pessoa, quer a segunda estrofe do poema "Bacanal" de António Navarro: "S. Vou fazer como se estivesse num festim. Vou bailar à roda da tua cabeça até cair sem vida. Vou dançar no funeral das coisas que morreram com a tua vida. Vê, vou fazer um bailado ao luar, para dizer tudo. [...] [Salomé] A noite é tão calma e tão puro o céu que não há tristeza que esteja fora de mim. Uma angústia como uma mão oprime-me. Há um desassossego sem esperança em todas as minhas emoções. Nesta hora morna e escura eu queria ser qualquer coisa que ninguém tivesse desejado ser." (Pessoa, 1986: 675-676-677); "O ar é um bailado de Salomé,/e a minha memória, pé ante pé,/seus passos, suas pernas e seus braços./" (presença, 1927: 6).
} 
Giovanni de Mozart e da nova edição, reformulada por Goethe, das Souffrances du jeune Werther. No entanto, enquanto D. João é um homem do palco (virado para o exterior), uma figura do espectáculo (brilhando na ribalta) e um usufruidor incontestável do momento presente, Werther é um herói moldado pelo Sturm und Drang, uma personagem ensimesmada no passado, um ser contemplativo e confinado ao seu eu, um leitor entusiasta de Ossian: "Ossian a supplanté Homère dans mon coeur. Quel monde que celui où me mène ce génie sublime! Errer sur les bruyères tourmentées par l'ouragan qui transporte les vapeurs du brouillard, les esprits des aïeux, à la pâle clarté de la lune; [...]" (1973: 121) ${ }^{15}$. Só a morte, unindo pelo desaparecimento a personagem operática, encarnação de uma aristocracia no início do declínio, e a personagem trágica do romance, jovem burguês romântico e céptico no que respeita à igualdade social, parece constituir o mitema comum, facultando a aproximação entre os dois mitos literários. Um outro paralelo poderá ser aventado entre o Fausto de Goethe ${ }^{16}$ (cuja primeira parte foi publicada em 1808, tendo sido dada ao prelo, em 1832, logo após a morte do autor, a parte segunda) e o Frankenstein or the modern Prometheus de Mary Shelley, romance surgido em 1818, que não se resume, do ponto de vista da Autora, a uma mera teia de terrores sobrenaturais, isento, como está, das "desvantagens inerentes às simples histórias de fantasmas e encantamentos". Curiosa se afigura, a todos os níveis, a estrutura desta obra, que oscila entre o romance epistolar e a diarística: se o incipit é constituído por quatro missivas [(Sampetersburgo), 11 de Dezembro de 17...; (Arcangel), 28 de Março de 17..; 7 de Julho de 17..; 5 de Agosto de 17...] endereçadas por R. Walton a sua irmã, Mrs. Saville, residente em Inglaterra, a partir de 13 de Agosto de 17... tem início o diário propriamente dito - cujo narrador intradiegético é Vítor Frankenstein -, espraiando-se por três epístolas à mesma destinatária, respectivamente datadas de 19 de Agosto de 17..., 26 de Agosto de 17.., 2 de Setembro de 17.., 5 de Setembro de $17 \ldots, 7$ de Setembro de $17 \ldots$, e culminando na última carta com data de 12 de Setembro. Quanto à narração em segundo grau de Frankenstein (narrativa que tem por

\footnotetext{
${ }^{15}$ A originalidade deste romance epistolar não pode passar em silêncio: diversamente das Lettres de la Religieuse portugaise, de Julie ou La Nouvelle Héloïse e das Liaisons dangereuses, Werther só tem um correspondente, de nome Wilhelm, que nunca responde nem aparece. No final do romance, surge uma terceira personagem, inominada e incógnita, que recolhe as cartas de Werther, que relata os últimos momentos da sua conturbada existência e que, sob a designação de "Éditeur", apela para o leitor. Nesta sequência, não podemos deixar de assinalar que o monstro criado por Frankenstein se revela um leitor exímio das Vidas Paralelas de Plutarco, de O Paraíso Perdido e de Os Sofrimentos do jovem Werther (obras achadas numa mala de cabedal abandonada na floresta), aprendendo com Werther, "fonte inesgotável de especulação e espanto", a tristeza e o desespero.

${ }_{16}$ No seu Primeiro Fausto, poema dramático, incompleto e fragmentário, Fernando Pessoa define magistralmente o tema fáustico: "O conjunto do drama representa a luta entre a Inteligência e a Vida, em que a Inteligência é sempre vencida. A Inteligência é representada por Fausto, e a Vida diversamente, segundo as circunstâncias acidentais do drama. [...] Outro modo de pôr o mesmo problema, ou, antes, a mesma tese:

1‥ Acto: Conflito da Inteligência consigo própria

2a . Acto: Conflito da Inteligência com outras Inteligências

3․ Acto: Conflito da Inteligência com a Emoção

4\%. Acto: Conflito da Inteligência com a Acção

5‥ Acto: Derrota da Inteligência." (1986: 605-607).
} 
narratário o Comandante Walton), ela é, igualmente, escandida por três cartas que o jovem recebe de Elizabeth Lavenza (Genebra, 18 de Março de 17...), do Pai, Afonso Frankenstein (Genebra, 12 de Maio de 17...), e, novamente, de Elizabeth Lavenza (Genebra, 18 de Maio de 17...). De realçar a génese deste romance, cuja 'chave' a Autora não se inibe de fornecer em "Prefácio" datado de [Marlow] Setembro de 1817: tendo passado nas imediações de Genebra, durante o Verão frio e chuvoso de 1816, alguns serões com os amigos, em volta da lareira, versando sobre "Ghost stories" alemãs, os veraneantes tomaram a decisão de cada qual escrever um romance sobre qualquer ocorrência sobrenatural, havendo sido Frankenstein, das três histórias previstas, a única a ser acabada e publicada.

Estes dois mitos literários (Fausto e Frankenstein) parecem ter sido 'contaminados' pelo mito de Prometeu, "porteur non du feu de la civilisation, mais de la flamme d'un désir inextinguible à laquelle l'humanité, si elle ne s'en garde, risque de se consumer." (Lecourt, 1998: 114). Se encararmos, porém, Frankenstein - cujo 'monstro' é dotado de uma indubitável consciência reflexiva ${ }^{17}$, bem como de uma humanidade ${ }^{18}$ e crueldade $^{19}$ inegáveis - em termos de derrisão de Prometeu - alvo de culto para os artistas do Enlightenment inglês, para os poetas do Aufklärung alemão e para os filósofos franceses do Século das Luzes -, não será a supra-referida 'contaminação' de matriz paródica? Ainda nesta ordem de ideias, não deixaria de ser interessante uma abordagem psicanalítica (cerca de um século antes de Freud...), ou, melhor dito, edipiana das figuras míticas de Frankenstein e de Drácula.

Gothic fiction [...] makes paternal abuse a major theme. [...] This paradigm which recurs from The Castle of Otranto through Dracula is prominent in Godwin's Caleb Williams and St. Leon. In Frankenstein, however, the son's oppression by the father informs not the plot of the novel but the mind of the protagonist. (Veeder, 1986: 143).

A abordagem diacrónica do mito, no âmbito literário e interartístico, é, todavia, mais frequente, conquanto as monografias elaboradas nesta perspectiva não raro se confrontem com os sempiternos problemas da exaustividade e da representatividade inerentes ao

\footnotetext{
17 "The monster saw my determination in my face, and gnashed his teeth in the impotence of anger. 'Shall each man', cried he, 'find a wife for his bosom, and each beast have his mate, and I be alone? I had feelings of affection, and they were requited by detestation and scorn. Man! You may hate, but beware! Your hours will pass in dread and misery, and soon the bolt will fall which must ravish from you your happiness forever. Are you to be happy, while I grovel in the intensity of my wretchedness?"' (Shelley, 1992: 162).

${ }^{18}$ Assim é que não se inibe de ajudar o ancião De Lacey, bem como a sua família, apanhando lenha suficiente para vários dias.

19 Transforma-se este anjo caído em demónio cruel ao assassinar Guilherme Frankenstein, Justina Moritz, Henrique Clerval e, por fim, Elizabeth Lavenza, esposa do protagonista-criador, tão amaldiçoado pela criatura... No explicit, e após o falecimento de Vítor Frankenstein, o monstro, face ao Comandante Walton, não hesita em subir para a pira funerária e em ser devorado, criação demoníaca, pelas labaredas.
} 
corpus a seleccionar ${ }^{20}$. Nada impede, com efeito, o investigador de se quedar nas afinidades entre Frankenstein e o cervantino Dom Quixote (1604).

Both Don Quixote and Frankenstein start out with the noble intention of helping their fellow-creatures, but their aspirations are doomed by their pursuit of a 'single vision', one that takes them further and further away from satisfying the moderate needs of the community, and nearer and nearer to a personally tragic denouement. (Hindle, 1992: xxxiv).

Ou, então, de atentar na evolução da pintura mitológica, analisando, numa perspectiva comparatista, "Oedipe et le Sphinx" de Ingres (1808), "Oedipe et le Sphinx" de Gustave Moreau (1864) e "Oedipus Rex" de Max Ernst (1922).

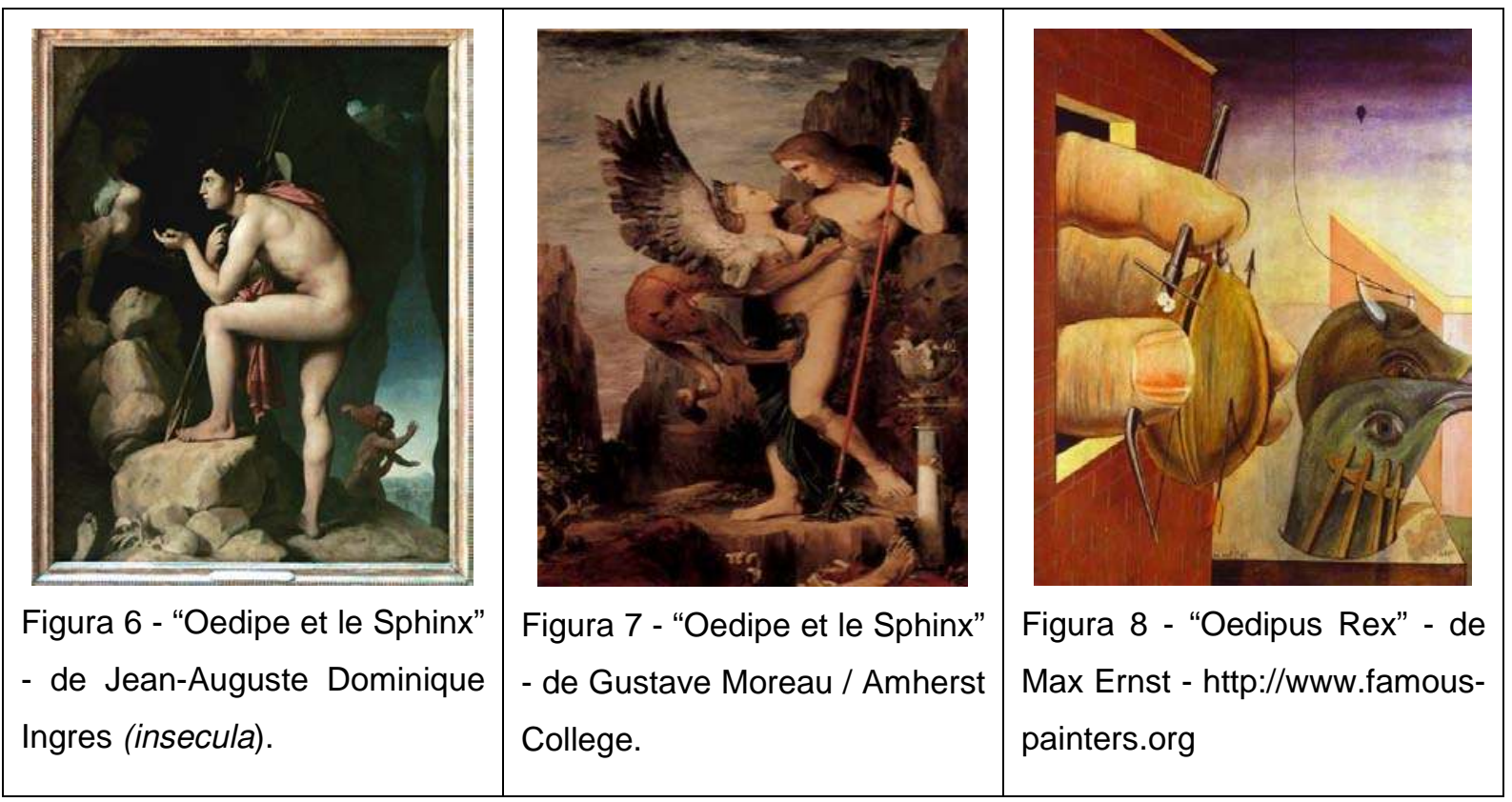

Ou, ainda, de estudar o mito de Orfeu apenas na música ${ }^{21}$, marginalizando a Invenção de Orfeu de Jorge de Lima, Les Sonnets à Orphée de Rainer Maria Rilke, o filme Orphée - adaptação de uma obra de Jean Cocteau protagonizada por Jean Marais - e a capa da revista Orfeu, inauguradora do (primeiro) modernismo português.

\footnotetext{
${ }^{20}$ Por vezes, esse corpus é tão extenso... que o resultado não deixa de ser algo infeliz. É o caso do filme "Van Helsing" de Stephen Sommers, com Hugh Jackman e Kate Beckinsale (E.U., 2004), que se afigura algo desordenado e excessivo: Van Helsing, caçador de monstros, enfrenta Drácula, Frankenstein e, até, o lobisomen...

${ }^{21}$ Ver, por exemplo, Orfeo ed Euridice de Gluck, ópera estreada em Viena a 5 de Outubro de 1762, sendo a belíssima ária do Terceiro Acto, "Che farò senza Euridice", o trecho mais célebre da ópera em questão; ver, também, Orfpheus in the Underworld, opereta de Jacques Offenbach que, estreada no "Théâtre des Bouffes Parisiens", a 21 de Outubro de 1858, escrita por Ludovic Halévy e, posteriormente, revista por Hector-Jonathan Crémieux, constitui uma paródia irreverente de Orfeo ed Euridice de Gluck; ver, por fim, The Soul of Orpheus, um álbum de textos musicais [Sally Bradshaw - soprano / Philip Collin - piano] inspirados pela Grécia antiga, no qual se destacam peças de Franz Schubert, Joahannes Brahms, Claude Debussy e Franz Josef Haydn.
} 
Ou, por fim, de optar pelo estudo de um mito numa só arte, a partir do texto fundador... Exemplifiquemos esta nossa via de investigação com o 'caso' do mito de Drácula - Vlad Tepes (nascido em 1431), voivode da Valáquia em 1448, de 1456 a 1462 e em 1476, cavaleiro cristão que lutou contra o expansionismo islâmico na Europa e suposto autor de certos actos de duvidosa veracidade -, explorado nas suas sucessivas versões cinematográficas a partir da obra do escritor irlandês Abraham 'Bram' Stocker (1847-1912) Dracula'guest and other weird sories (Constable, 1897) -, publicada em 1914 por Florence Stoker. Não seria de interesse inegável o cotejo entre o incipit do romance e o incipit das realizações fílmicas mais marcantes, focando particularmente a metamorfose da personagem, folclórica e lendária, em figura mítica?

1922 - Nosferatu, le vampire / Real. F. W. Murnau

1931 - Dracula / Real. Tod Browning

1958 - Le cauchemar de Dracula / Real. Terence Fisher

1979 - Dracula / Real. John Badham

1993 - Drácula / Real. Francis Ford Coppola

Ou até, fazendo apelo à imagologia ${ }^{22}$, a análise da(s) representação(ções) da Transilvânia configurando a 'saga' não do Príncipe feliz de Oscar Wilde, mas do Príncipe das Trevas?

Quelques connaissances de la région ne me [Jonathan Harker] feraient évidemment aucun tort, puisque je devais traiter avec un gentilhomme de là-bas. Je découvris que la région à laquelle il faisait allusion s'étendait en bordure de trois États: la Transylvanie, la Moldavie et la Bukovine, tous trois au milieu des Carpates, une des régions les plus sauvages et les moins connues de toute l'Europe. Par contre, ouvrages et plans ne m'ont pas permis de localiser le château de Dracula - il n'existe

\footnotetext{
22 Segundo Jean-Marc Moura (2005: 205-215), a imagologia pode ser definida como o estudo das imagens literárias do estrangeiro, provenientes da oposição eu/outro, identidade/alteridade. Atentemos nalguns exemplos fornecidos por Bram Stoker: "II [le comte] poursuivit: - Nous sommes en Transylvanie, et la Transylvanie, ce n'est pas l'Angleterre. Nos coutumes ne sont pas les vôtres, et vous verrez encore bien d'étranges choses." (2006: 39); "Une bande de Tziganes est arrivée au château [...] en Transylvanie [...] ils sont considérés comme hors-laloi. [...] ils parlent leur propre langue, un dialecte issu du roumain." (2006: 65-66); "J'ai [Quincey Morris] entendu dire que le comte venait d'un pays de loups et qu'en fin de compte il pouvait y arriver avant nous." (2006: 425); "Dieu soit loué: ce pays est une merveille en ce sens que la corruption règne en maîtresse absolue - [...] ("Journal de Jonathan Harker") (2006: 438); "Van Helsing secoua la tête. - J'ai bien peur que ce ne soit impossible. Ce pays est bien différent du vôtre [Lord Godalming] et du mien." (2006: 443); "Le pays semble plus immense à mesure que nous avançons. L'énorme chaîne des Carpates [...] semble à présent nous encercler et former devant nous un obstacle infranchissable." ("Journal de Mina Harker)" (2006: 473); "Nous avons alors regardé en arrière, et vu le château de Dracula qui se dessinait, net, précis, dans le ciel." (“Journal de Mina Harker") (2006: 485).
} 
d'ailleurs, de cette région particulière, aucune carte qui puisse se comparer à nos cartes d'état-major. (Stoker, 2006: 16) ${ }^{23}$.

Detendo-nos na última versão cinematográfica que transmuda Vlad III, 'o Empalador', em Vlad III, 'o Vampiro', forçosa se torna assinalar a adaptação fiel de Coppola à novela, bem documentada ${ }^{24}$, de Stoker: 1) Os protagonistas, o verdadeiro e o ficcional, têm o mesmo nome e prosopografia idêntica; 2) Algumas cenas do filme corroboram a não traição à História, graças ao culto da documentação do realizador.

Um outro contributo inovador dos Estudos Interartes diz respeito à mudança de tratamento dispensado à ilustração, encarada não como uma interpretação, mas como uma reescrita e como uma tradução: numa reversão das práticas anteriores, tende-se a ver a relação entre o texto-fonte e o texto-alvo, não sob o ângulo do primeiro, mas na perspectiva do último. Um exemplo flagrante é $O$ enigma da Atlântida, de Edgar P. Jacobs - tendo como protagonistas o Professor Mortimer e o seu velho amigo Capitão Blake -, que reescreve, em certa medida, quer a Atlântida do ponto de vista geográfico (desde o seu apogeu, passando pela decadência paulatina patente na sua 'redução' às ilhas de Routa e de Daytia, até à catástrofe final que se abateu sobre a ilha de Posídon), quer a pluralidade das 'Atlântidas' (a Atlântida antiga, a Atlântida esotérica e misteriosa e a Atlântida poética e romanesca), quer alguns fragmentos do Crítias e do Timeu de Platão.
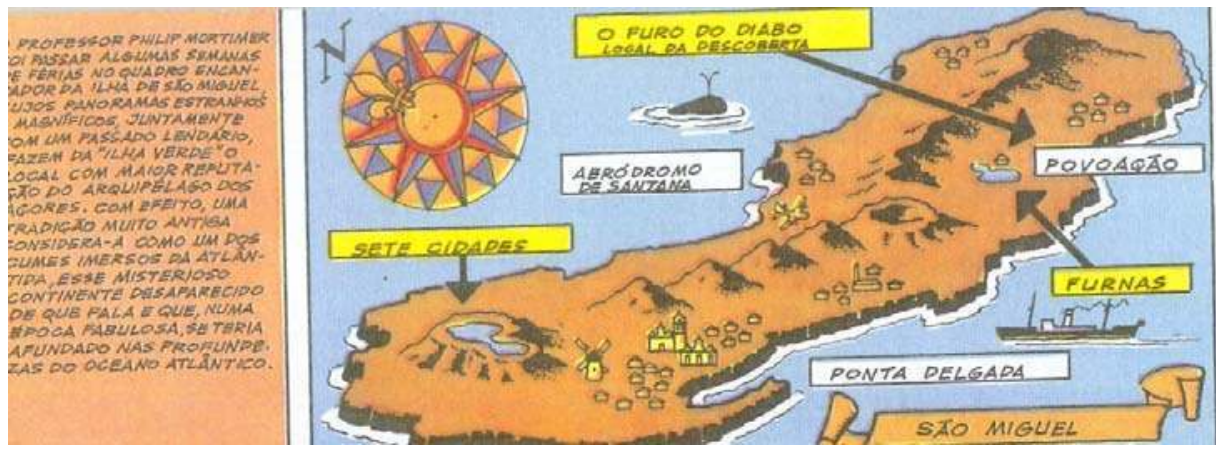

Figura 9 - Jacobs, 1980: 3.

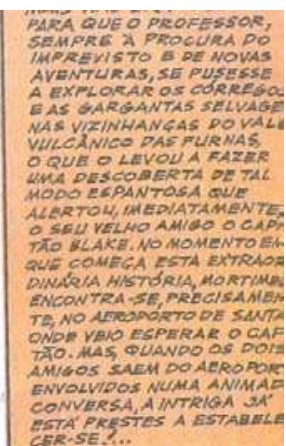

DTA RRESTES A ESTABEL

\footnotetext{
${ }^{23}$ É evidente que, em 1897, Bram Stoker não deveria conhecer a belíssima cidade medieval de Sighisoara, nem - "Turnul cu Ceas si Casa Vlad Druc". Do mesmo modo, não poderia ter acesso ao artesanato artístico transilvano 'exportado' como "souvenir": uma peça de madeira representando em relevo o Castelo do Drácula "Castelul 1377 Dracula" -, dois ou três pinheiros reenviando aos Cárpatos, uma efígie do Empalador... sorridente e uma esclarecedora etiqueta de marketing: "O tara cu o civilizatie multimenara cu un patrimoniu istoric si cultural considerabil".

${ }^{24}$ Hermann (Arminius) Vambery é, à imagem do Drácula, uma personagem histórica. Professor de Línguas Orientais na Universidade de Budapeste, foi o principal informador de Bram Stoker, quer no tocante a esta lenda da Transilvânia, quer no que respeita ao folclore romeno, quer no que concerne ao vampirismo: "J'ai demandé [docteur Van Helsing] à mon ami Arminius, de I'Université de Budapest, de me faire un compte rendu concernant la personnalité de Dracula. Je l'ai reçu récemment. Notre ennemi doit être, sans doute le voïvode Dracula qui a gagné son surnom pendant la guerre contre les Turcs qu'il alla porter de l'autre côté du grand fleuve, sur le territoire turc lui-même. [...] Selon Arminius, toujours, les Dracula appartenaient à une grande et noble race, encore que, de temps à autre, certains d'entre eux eussent entretenu des rapports avec le Malin [...]" (2006: 319320).
} 
De destacar, nesta feliz ilustração em banda desenhada, a referência a uma tradição muito antiga que considera a "Ilha Verde" como um dos cumes imersos da Atlântida (1980: 3), o prodigioso labirinto de corredores e escadarias desembocando num vasto átrio magnificamente decorado, atestando o carácter sumptuoso da civilização perdida (1980: 19), a detecção do oricalco radioactivo, inesgotável fonte de energia (1980: 22), e o imenso complexo de grutas colossais, ligadas por passagens, canais e lagos (1980: 24). Até que, certo dia, a sumptuosa Atlântida, de acordo com a narrativa platónica, foi submersa, desaparecendo para sempre da superfície da terra:

Or dans cette île Atlantide, des rois avaient formé une grande et admirable puissance, qui étendait sa domination sur l'île entière et sur beaucoup d'autres îles et quelques parties du continent. En outre, en deçà du détroit, de notre côté, ils étaient maîtres de la Libye jusqu'à l'Égypte et de l'Europe jusqu'à la Tyrrhénie. Or, un jour, cette puissance, réunissant toutes ses forces, entreprit d'asservir d'un seul coup votre pays, le nôtre et tous les peuples [...] Ce fut alors, Solon, que la puissance de votre cité fit éclater aux yeux du monde sa valeur et sa force. [...] Mais dans le temps qui suivit, il y eut des tremblements de terre et des inondations extraordinaires et, dans l'espace d'un seul jour et d'une seule nuit néfastes, tout ce que vous aviez de combattants fut englouti d'un seul coup dans la terre, et l'île Atlantide, s'étant abîmée dans la mer, disparut de même. (1939: 456-457).

$\mathrm{Na}$ banda desenhada de Edgar Jacobs, datada de 1955, visualizamos não só "o espectáculo grandioso e alucinante das ruínas duma imensa cidade submersa", "destruída pelas águas há mais de dez mil anos" (1980: 62), mas também a Atlântida subterrânea, construída nas entranhas da terra", qual "novo império [...] da ciência e da sabedoria" (1980: 22), assistindo, no explicit, à viagem dos Atlantes rumo ao espaço... ${ }^{25}$

\footnotetext{
${ }^{25}$ Não constituirá esta viagem ao espaço, assim como a referência aos discos-voadores, uma antecipação (de catorze anos) da primeira viagem à Lua, a 20 de Julho de 1969, dos astronautas da Apollo 11? Ver, ainda, a revitalização do mito da Atlântida quer através dos quadros Portas da Atlântida (2000) e A queda da Atlântida (2001) de Ana Garrett, quer através dos romances O Mistério da Atlântida de David Gibbins (o arqueólogo Jack Howard localiza um navio naufragado, onde se encontram vestígios que remontam a quinze mil anos A.C.) e $A$ queda da Atlântida de Marion Zimmer Bradley (a história de duas irmãs, Deoria e Domaris, filhas do Sumo Sacerdote Talkannon).
} 

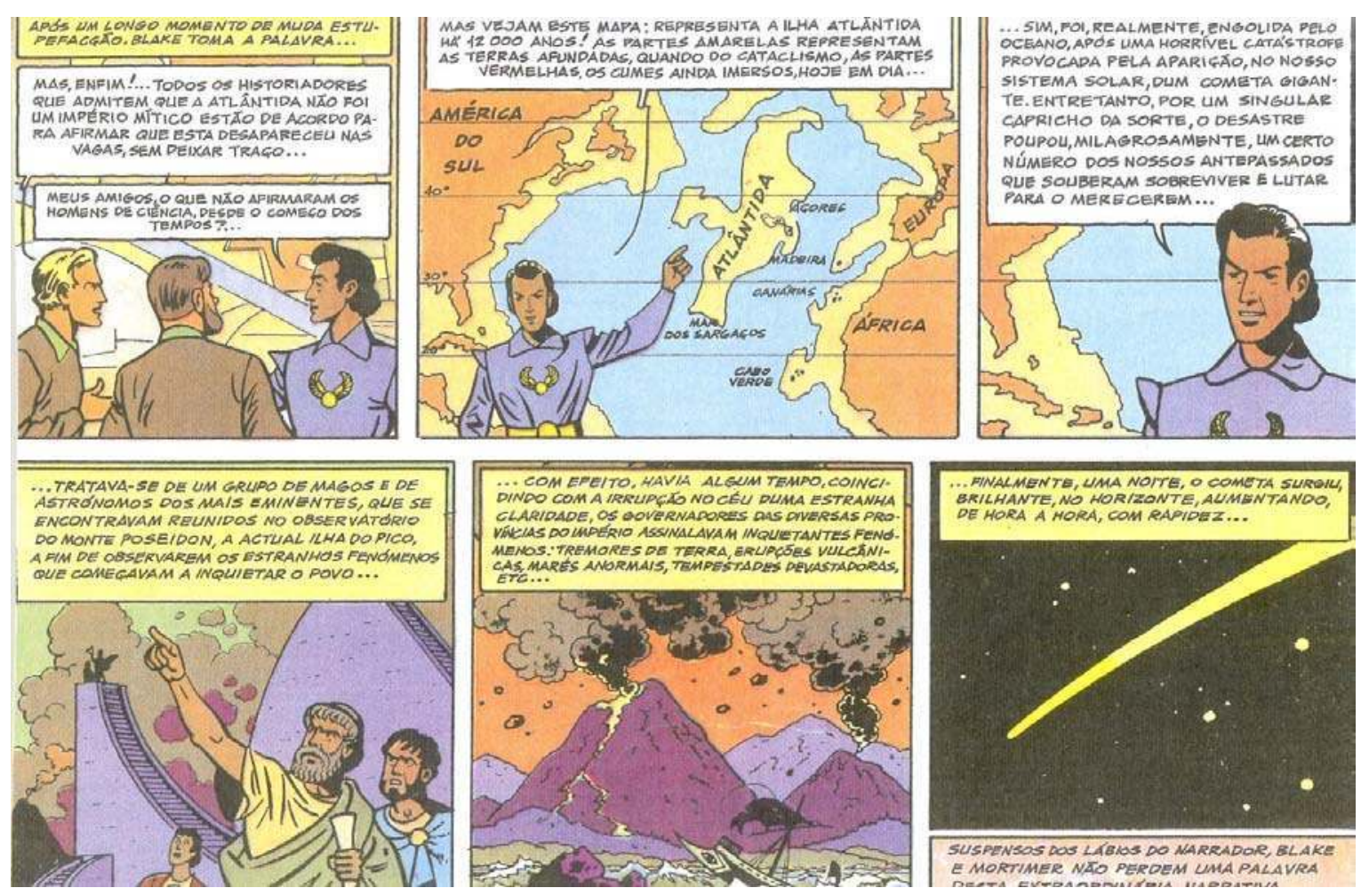

Figura 10 - Jacobs, 1980: 21.

Hoje em dia, os Estudos Interartes constituem um veículo essencial de expansão e de modernização do mito, tendendo para os jogos interactivos, para os vídeo-clips musicais, para a arte halográfica e ambiental, praticando um sincretismo por vezes brutal e amalgamando substratos míticos diversos: se as Fábulas de La Fontaine, oriundas do 'tempo em que os animais falavam', foram transpostas, ainda numa perspectiva interartística tradicional, para baralho de cartas ao serviço do "Jogo das Famílias" -, já a mítica cidade de Pompeios, cenário da novela Arria Marcella de Théophile Gautier e da Gradiva de Wilhelm Jensen, foi virtualmente reconstruída, graças às novas tecnologias ${ }^{26}$.

\footnotetext{
${ }^{26}$ Ver também, a este respeito, Colosseo Gladiatori. Con immagini virtuali di Pompei e dell'antica Roma (scritto e diretto da Aldo Zappalà), Time Travellers.
} 


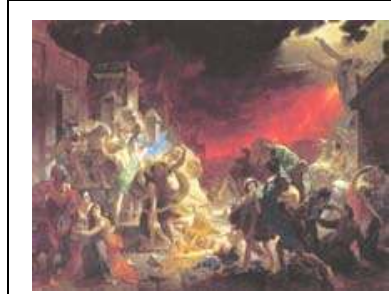

Figura 11 - O último dia de Pompeios por Karl Pavlovic Bryullov (1833), que remete para o único testemunho da catástrofe: a carta de Plínio-o-Moço https://www.alliance 2.tripod.com/academia russa.html

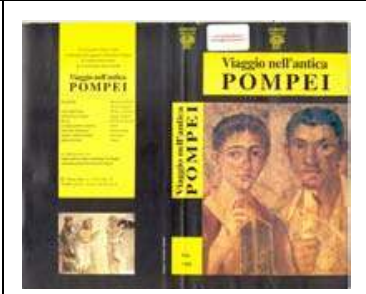

Figura 12 - Neste belíssimo documentário, intitulado Viaggio nell'antica Pompei, é-se confrontado com um curioso bailado: os vivos dançam com as "impronte umane".

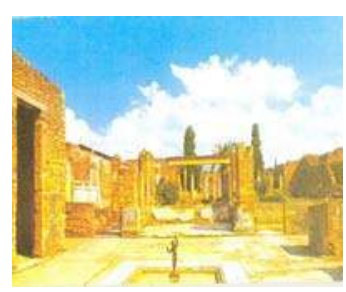

Figura 13 - "La casa del Fauno" (tal como pode ser actualmente visitada) (1996: 27).

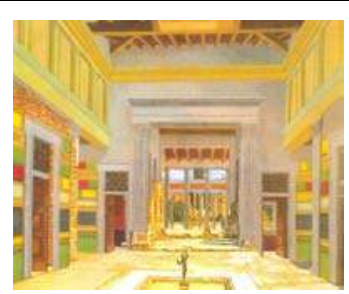

Figura 14 - "La casa del Fauno" (virtualmente reconstituída) (1996: 27).

Neste contexto específico, é importante assinalar que a Ópera Nacional de Paris levou a palco, em 2007, um bailado de Rolland Petit, que é, simultaneamente, um filme de Vincent Bataillon, narrativa não verbal da Recherche proustiana - intitulada "Proust ou les Intermittences du coeur" -, revisitada através dos momentos/episódios a seguir transcritos e assim intitulados pelos sujeitos reescreventes.

1. "La petite phrase de Vinteuil ou la musique des amours".

2. "Les aubépines ou les mots fées".

3. "Faire catleya ou les métaphores de la passion".

4. "Les jeunes filles en fleurs ou les vacances enchantées".

5. "Albertine et Andrée ou la prison et les doutes".

6. "La regarder dormir ou la réalité ennemie".

7. "Monsieur de Charlus face à l'insaisissable".

8. "Monsieur de Charlus vaincu par l'impossible".

9. "Les enfers de Monsieur de Charlus".

10. "Rencontre fortuite dans l'inconnu".

11. "Morel et Saint-Loup ou le combat des anges".

12. "Cette idée de la mort..." 
Não está só em jogo o impacto da imaginação do artista na produção da obra de arte $^{27}$, mas também, e sobretudo, a recepção do leitor : assim, para um conhecedor da obra de Proust, a narrativa não verbal que é o bailado fílmico reenvia de imediato a episódios fulcrais dos vários volumes da Recherche, desde Combray e Un amour de Swann até $A$ l'ombre des jeunes filles en fleurs e Sodome et Gomorrhe, conhecendo Le temps retrouvé uma verdadeira apoteose, mercê da mímica, no final da peça, da gesticulação (mecânica e desconjuntada) e da caracterização (cabelos brancos e costas curvadas) dos protagonistas. No entanto, para um espectador não familiarizado com a obra de Proust, a mensagem afigura-se, por certo, dúbia: uma narrativa em que as cenas de lesbianismo, homossexualidade e sado-masoquismo proliferam...

E que dizer, nos meandros deste zapping interartístico-cultural, da televisão portuguesa que imortalizou, nos decénios de 60 e de 70, nomes sonantes e programas inesquecíveis? Foi o caso de um comunicador exímio, autor de uma "Arte Poética" escrita em língua francesa, que a seguir se transcreve com o intuito de the render preito no trigésimo aniversário do seu falecimento.

\section{Art Poétique}

L'imprécision, caresse d'or,

Fuit mes doigts trop grossiers

Et, sur les dalles, mes pieds

Refoulent tout le décor.

La nuit gonfle mon être de vacarme

Et les étoiles se disposent

Comme des piqûres sur ma peau:

Puis je déteste les roses,

En profitant de mes larmes

Pour bouillir, comme de l'eau.

Si les poètes misérables

Eussent voulu saisir le monde,

\footnotetext{
${ }^{27}$ Para Platão, por exemplo, "Ce n'est pas en effet par art, mais par inspiration et suggestion divine que tous les grands poètes épiques composent tous ces beaux poèmes" (Ion: 534e-535a); para Kant (Critique du Jugement), a arte é uma "habileté de l'homme" (1970: 130-131); para Schiller [Correspondance entre Schiller et Goethe (1923: 148-149)], a experiência ensina "que le poète prend son unique point de départ dans l'inconscient"; para Nietzsche [Humain trop humain (1910)], "ce sont surtout les artistes de l'expression qui passent pour géniaux"; para Paul Valéry [Variété V (1944: 102-104)], é impensável a distinção entre "l'état de poésie" e a "action complète et soutenue de l'intellect." Ainda nesta ordem de ideias, Oscar Wilde é de parecer que o excesso de intenções intelectuais por parte do artista pode 'estragar' a obra de arte. Nesta sequência, Gilbert confessa a Ernest: "The longer I study, Ernest, the more cleary I see that the beauty of the visible art is, as the beauty of music, impressive primarily, and that it may be marred, and indeed often is so, by any excess of intellectual intention on the part of the artist." (1997: 841). Ver, a respeito da obra de arte e da imaginação, Picon, Pierre (1972: 7-16).
} 
Ils n'y enfonceraient qu'une lance véritable;

Leur sang durci de peur, la joie l'inonde.

Allons, allons, à l'assaut de la vie,

Tous couronnés de vent,

Contre ce lâche mot,

Beauté, Beauté, halali!

Sous nos cuisses de fer hennissent les chevaux

Vers une autre Poésie

Qui se dévoile en avant. (1989: 82).

Foi professor universitário. Distinguiu-se na ficção, no romance e na novela. Tornouse um inveterado cronista. Legou à posteridade uma importante produção científica, no que respeita à crítica literária e ao ensaio. Inventou o conceito de "açorianidade", decalcado na "hispanidad" de Unamuno.

E chamou-se Vitorino Nemésio... Se bem me lembro... 


\section{Bibliografia}

Chefs d'œuvre de la peinture impressionniste et post-impressionniste (1996). New-York - Paris Londres : Éditions Abbeville.

CHEVReL, Yves (2006). La littérature comparée. Paris : puf, col. "Que sais-je?"

CLÜVER, Claus (2001). "Estudos interartes: introdução crítica”. In: Helena Buescu, João Ferreira Duarte, Manuel Gusmão (orgs.). Floresta Encantada: Novos caminhos da literatura comparada. Lisboa: Publicações Dom Quixote, pp. 333-359.

Colosseo Gladiatori. Con immagini virtuali di Pompei e dell'antica Roma (scritto e diretto da Aldo Zappalà), Time Travellers.

CROCE, Benedetto (2001). Breviario di estetica / Aesthetica in nuce. Milano: Adelphi Edizioni, col. "Piccola Biblioteca 243".

CUSSET, Cristophe (1999). La mythologie grecque. Paris : Seuil.

BRUNEL, Pierre (1988). Dictionnaire des mythes littéraires (dir). Paris : Éditions du Rocher, Jean-Paul Bertrand.

FranZINI, Elio e MAZZOCUT-MIS, Maddalena (1996). Estetica. I nomi, i concetti, le correnti. Milano: Edizione Bruno Mondadori.

FUMAROLI, Marc (2003). "Préface" de À Rebours. Paris: Gallimard, col. "folio classique".

GADAMER, Hans-Georg (2006) [1.. edición - 1996]. "Palabra e imagen" ('Tan verdadero, tan siendo')". In: Estética y Hermenéutica. Traducción de Antonio Gómez Ramos. Introducción de Ángel Gabilondo. Madrid: Editorial Tecnos, Tercera Edición, pp. 279-307.

GENETTE, Gérard (2007). "A obra de arte - imanência e transcendência". In: Kelly Basílio [coord.], Mário Jorge Torres, Paula Morão, Teresa Amado (orgs). Concerto das Artes. Porto: Campo das Letras - Editores, S. A., 1. 르 edição, pp. 15-37.

GOETHE, Johann Wolfgang (1973). Les Souffrances du jeune Werther. Traduction de Bernard Groethuysen. Préface et notes de Pierre Bertaux. Paris: Gallimard, col. "folio classique".

GUIMARÃES, Fernando (2003). Artes Plásticas e Literatura. Do Romantismo ao Surrealismo. Porto: Campo das Letras, col. "Campo da Literatura/Ensaio".

HINDLE, Maurice (1992). "Introduction" a Frankenstein or the modern Prometheus. London: Penguin Books, col. "Penguin Classics".

HUYSMANS, Joris-Karl [Charles-Marie-Georges] (2003). À Rebours. Paris: Gallimard, col. "folio classique".

JACOBS, Edgar P. (1980). O enigma da Atlântida. Aventuras de Blake e Mortimer. Tradução de Marília Alves. Lisboa: Livraria Bertrand, SARL.

KEMP, Sandra (1993). "Introduction" às Selected Short Stories (Virginia Woolf). London: Penguin Books.

KRIEGER, Murray (2007). "Imagem e palavra, espaço e tempo: a exaltação - e a exasperação - da ekphrasis". In: Kelly Basílio [coord.], Mário Jorge Torres, Paula Morão, Teresa Amado (orgs). Concerto das Artes. Porto: Campo das Letras - Editores, S. A., 1. ㄹ edição, pp. 133-163.

LeCOURT, Dominique (1998). Prométhée, Faust, Frankenstein. Fondements imaginaires de l'éthique. Paris : col. "Le Livre de Poche", bibliolessais.

MACHADO, Álvaro Manuel (1983). A Arte da fuga. Mem Martins.

MAZZOCUT-MIS, Maddalena e FRANZINI, Elio (1996). Estetica. I nomi, i concetti, le correnti. Milano : Edizione Bruno Mondadori.

MONNEYRON, Frédéric e ThOMAS, Joël (2002). Mythes et littérature. Paris: puf, col. "Que sais-je?"

MOURA, Jean-Marc (2005). "Imagologie littéraire et mythe". In : Questions de Mythocritique.

Dictionnaire. Sous la direction de Danièle Chauvin, André Siganos et Philippe Walter. Paris:

Éditions Imago, pp. 205-215. 
MUKAROVSKI, Jan (1990) [1. e edição - 1981]. Escritos sobre Estética e Semiótica da Arte. Lisboa: Editorial Estampa, col. "Imprensa Universitária".

NemÉsıo, Vitorino (1989). Obras Completas. Poesia. Introdução, organização e fixação do texto de Fátima Freitas Moura. Lisboa: Imprensa Nacional - Casa da Moeda, vol. I.

PESSOA, Fernando António Nogueira (1986). Obra Poética e em Prosa. Porto: Lello \& Irmão Editores, vol. I.

PESSOA, Fernando António Nogueira (1986). Obra Poética e em Prosa. Porto: Lello \& Irmão Editores, vol. III.

PICON, Pierre (1972). L'oeuvre d'art \& l'imagination. Textes et documents philosophiques. Textes choisis et présentés par Pierre Picon. Paris: Librairie Hachette, col. "Classiques Hachette".

PLATON (1939). Oeuvres Complètes. Paris : Librairie Garnier-Frères, col. "Classiques Garnier".

Pompei. Ercolano. Come erano e come sono con ricostruzioni dei monumenti antichi (1996). Roma: VISION.

PrAZ, Mario (1982). Literatura e Artes Visuais. São Paulo: Editora Cultrix.

Proust, Marcel (1984). À la recherche du temps perdu. Édition établie par Pierre Clarac et André Ferré. Paris : Gallimard, nrf, col. "Bibliothèque de la Pléiade", vol. I.

Proust, Marcel (1999). À la recherche du temps perdu. Combray. Adaptations et dessins de Stéphane Heuet. Couleurs de Véronique Dorey. Luçon : Guy Delcourt Productions.

REMO, Bodei (1997). Le forme del bello. Bologna: Società editrice il Mulino, col. "Lessico dell'Estetica".

RUIPEREZ, Martín S. (2006). El mito de Edipo. Lingüística, psicoanálisis y folklore. Madrid : Alianza Editorial, S.A., col. "Humanidades /Religión y mitología".

SelLIER, Philippe (1984). "Qu'est-ce qu'un mythe littéraire". In : Littérature, no 55.

SHELLEY, Mary (1992). Frankenstein or the modern Prometheus. London : Penguin Books, col. "Penguin Classics".

SOURIAU, Étienne (1969). La Correspondance des Arts. Paris : Flammarion, col. "Science de l'Homme".

STOKER, Bram (1992). Dracula suivi de L'Invité de Dracula. Traduction de Jacques Finné. Présentation et commentaires de Claude Aziza. Paris : Pocket.

THOMAS, Joël e MONNEYRON, Frédéric (2002). Mythes et littérature. Paris: puf, col. "Que sais-je?"

VEEDER, William (1984). Mary Shelley and Frankenstein. The Fate of Androgyny. Chicago and London: The University of Chicago Press.

Viaggio nell'antica Pompei. Ideazione di Salvatore Raiola e di Nicola Gargiulo. In collaborazione con Sopritendenza Beni Archeologici di Pompei/Amministrazione Provinciale di Napoli. Pompei: d'Oriano Editore.

WERNER, Waldmann (1998) [1 $1^{a}$ edição - 1983]. Virginia Woolf. Tradução de Maria Emília Ferros Moura. Lisboa: Círculo de Leitores.

WILDE, Oscar (1997). "The critic as Artist - A Dialogue in Two Parts". In: Collected Works of Oscar Wilde. The Plays, the Poems, the Stories and the Essays including De Profundis. Hertfordshire: Wordsworth Editions.

WoOLF, Virginia (1992) [1. a edição - 1931]. The Waves. London: Penguin Books.

Woolf, Virginia (1994). Cartas íntimas a Vita Sackeville-West. Tradução de Ana Fontes. Sintra: Colares Editora.

Word \& Image. A Journal of verbal/visual enquiry (January-March 2008). University of Pennsylvania, Vol. 24, no 1 .

WUNENBURGER, Jean-Jacques (2005). "Création artistique et mythique". In : Questions de Mythocritique. Dictionnaire. Sous la direction de Danièle Chauvin, André Siganos et Philippe Walter. Paris: Éditions Imago, pp. 69-84. 
[disponível em 08/12/02] <URL: http://www.famous-painters.org/Max-Ernst/Oedipus-Rex.shtm> [disponível em 08/12/02] <URL: http://www.insecula.com/oeuvre/photo_ME0000101141.HTML> [disponível em 08/12/02] <URL:

https://www.amherst.edu.academiclife/departments/courses/07085/FREN/FREN/FREN>

[disponível em 09/12/15] <URL:

https://www.alliance2.tripod.com/academia_russa.html 